\title{
Concentrations of chlorinated and brominated contaminants and their metabolites in serum of harbour seals and harbour porpoises
}

\author{
Liesbeth Weijs ${ }^{a, b, *}$, Krishna Das ${ }^{c}$, Ursula Siebert ${ }^{\mathrm{d}}$, Niels van Elk ${ }^{\mathrm{e}}$, Thierry Jauniaux ${ }^{\mathrm{f}}$, Hugo Neels ${ }^{\mathrm{b}}$, \\ Ronny Blust ${ }^{\mathrm{a}}$, Adrian Covaci ${ }^{\mathrm{a}, \mathrm{b}}$ \\ ${ }^{a}$ Laboratory of Ecophysiology, Biochemistry and Toxicology, Department of Biology, University of Antwerp, Groenenborgerlaan 171, 2020 Antwerp, Belgium \\ b Toxicological Centre, University of Antwerp, Universiteitsplein 1, 2610 Antwerp, Belgium \\ ${ }^{c}$ Laboratory for Oceanology-MARE Center, University of Liège B6C, 4000 Liège, Belgium \\ ${ }^{\mathrm{d}}$ Forschungs- und Technologiezentrum Westküste, University of Kiel, Hafentörn 1, 25761 Büsum, Germany \\ e Dolfinarium Harderwijk, Strandboulevard 1, 3841 Harderwijk, The Netherlands \\ ${ }^{\mathrm{f}}$ Département de Morphologie et Pathologie, Pathologie générale et Autopsies, University of Liège B43, 4000 Liège, Belgium
}

\section{A R T I C L E I N F O}

Article history:

Received 19 January 2009

Accepted 9 February 2009

Available online 20 March 2009

\section{Keywords:}

Harbour seals

Harbour porpoises

North Sea

Serum

PCBs

PBDEs

MeO-PBDES

HO-PCBs

Metabolites

\begin{abstract}
A B S T R A C T
Harbour seals (Phoca vitulina) and harbour porpoises (Phocoena phocoena) are top predators in the North Sea and consequently accumulate a variety of pollutants in their tissues. Concentrations of polychlorinated biphenyls (PCBs), polybrominated diphenyl ethers (PBDEs) and their hydroxylated metabolites (HO-PCBs and HO-PBDEs) were measured in serum of wild harbour seals $(n=47)$ and captive harbour porpoises $(n=21)$. Both species exhibit long life spans and do not have extreme situations, such as complete fasting during periods of lactation, in their annual cycles. For PCBs, concentrations in adult males were slightly higher than in juveniles and lowest in juvenile females. For PBDEs, juveniles have higher levels than adult males and females, probably as a consequence of lactational transfer. However, differences between these age-gender groups were not statistical significant, indicating that individual variation was limited within each species, even without knowing the feeding status of the animals. Body condition, particularly emaciation, has a major influence on the levels of chlorinated and brominated contaminants in serum. Profiles of PCBs were CB 153>CB 138>CB 187>CB 180 and CB 153>CB 138>CB 149>CB 187>CB 180 for harbour seals and porpoises respectively. For PBDEs, BDE 47 was the predominant congener followed by BDE 100 and 99 in both species. In harbour seals, concentrations of sum PCBs (median: 39,200 pg/ml) were more than 200 times higher than levels of sum PBDEs (median: $130 \mathrm{pg} / \mathrm{ml}$ ) and almost 10 times higher than concentrations of sum HO-PCBs $(4350 \mathrm{pg} / \mathrm{ml}$ ). In harbour porpoises, concentrations of sum PCBs (median: 24,300 pg/ml) were about 20 times higher than concentrations of PBDEs (median: $1300 \mathrm{pg} / \mathrm{ml}$ ). HO-PCBs were detected in only 4 harbour porpoises and this at very low concentrations. Naturally-produced MeOPBDEs were only found in harbour porpoises at concentrations ranging from 120 to $810 \mathrm{pg} / \mathrm{ml}$. HO-PBDEs were not found in any species. In general, harbour seals accumulate less compounds and have mostly lower concentrations than harbour porpoises possibly as a result of a better developed metabolism.
\end{abstract}

(c) 2009 Elsevier Ltd. All rights reserved.

\section{Introduction}

The bioaccumulative potential and toxicity of polychlorinated biphenyls (PCBs) and polybrominated diphenyl ethers (PBDEs) as well as pesticides (hexachlorobenzene (HCB), dichloro-diphenyl-trichloroethane (DDT) and metabolites) in marine mammals have been the focus of numerous papers worldwide (Tanabe et al., 1994; Bruhn et al., 1995; Reijnders and Aguilar, 2002; Reijnders and Simmonds, 2003; Thron et al.,

\footnotetext{
* Corresponding author. Laboratory of Ecophysiology, Biochemistry and Toxicology, University of Antwerp, Groenenborgerlaan 171, Building U, 5th Floor, 2020 Antwerp, Belgium. Tel.: +32326535 41; fax: +3232653497.

E-mail address: liesbeth.weijs@ua.ac.be (L. Weijs).
}

2004; Ross, 2006). These types of chlorinated and brominated contaminants have been associated with immunological, reproductive and mostly endocrine/cytotoxic (e.g. thyroid hormone action) effects in various marine mammal species and, due to their persistence in the environment, are still a threat to the health condition of aquatic organisms in general (Damstra et al., 2002; Beineke et al., 2005; Das et al., 2006; Bossart, 2007). Among these, PCBs and PBDEs are assumed to have comparable toxic action mechanisms since they have similar chemical properties (de Boer et al., 1998; Birnbaum and Staskal, 2004). Despite their ban in Europe (PCBs in 1970s, most PBDE congeners in 2004), both types of contaminants can still be found at all levels of the aquatic food chains (Ruus et al., 1999; Boon et al., 2002).

PCBs and PBDEs may undergo metabolic/enzymatic breakdown resulting in methylsulfone and hydroxylated PCB and PBDE metabolites 
(Letcher et al., 2000) or lower brominated PBDE congeners (Letcher et al., 2000; Birnbaum and Staskal, 2004). Debromination of PBDEs into lower brominated congeners has been shown to occur in a few terrestrial and aquatic organisms such as birds (Pirard and De Pauw, 2007; Van den Steen et al., 2007), rats (Huwe and Smith, 2007) and fish (Stapleton et al., 2004; Benedict et al., 2007). Although methylsulfone and hydroxylated metabolites are more polar and consequently easier to eliminate from the body than their parent compounds, considerable amounts of these metabolites are retained in the body of several species (Sandala et al., 2004; Gebbink et al., 2008; Jaspers et al., 2008). Hydroxylated metabolites can be formed by direct insertion of a HOgroup or by formation of an arene oxide intermediate that rearranges to a HO-group. Both ways are possible, but the extent to which each pathway occurs is probably highly dependent of the species (Letcher et al., 2000). Effects of these metabolites are mostly related to disturbances of hormonal and endocrine systems as they can bind to and interact with several hormone receptors and transport proteins (Cheek et al., 1999; Birnbaum and Staskal, 2004; Shimokawa et al., 2006). As a result, toxic effects can have a great impact on the health condition of organisms in general. Hydroxylated metabolites are not particularly associated with lipids as can be seen for the parent compounds, but have a high affinity for plasma proteins. Therefore, they can primarily be found in blood (Gebbink et al., 2008).

Harbour seals (Phoca vitulina) and harbour porpoises (Phocoena phocoena) are common marine mammals in West-European waters (Burns, 2002; Hammond et al., 2002). They are known to accumulate high contaminant concentrations in their tissues because of their longer life spans and top-position in aquatic food chains (Shaw et al., 2005, 2007). Although seasonal changes in blubber thickness may occur, both species do not have extreme fasting periods in their annual cycles as both species continue eating during their reproductive and lactational periods (Kastelein et al., 1997; Burns, 2002; Lockyer, 2007). Weijs et al. (2009a) suggested a higher capacity in harbour seals for metabolizing PCBs and PBDEs compared to harbour porpoises. However, considering the assumed toxicity of the resulting metabolites (Meerts et al., 2000; Birnbaum and Staskal, 2004) and their presence in blood, concerns have been raised about the higher metabolic capacity of harbour seals in terms of their global health and the conservation of marine mammals on a longer term.

While extensive studies described PCBs and PBDEs in blubber and other tissues of caught or stranded marine mammals, fewer data were documented in blood of free-ranging seals and harbour porpoises (Bang et al., 2001; Sørmo et al., 2003; Sørmo, 2005). Levels of persistent organic pollutants (POPs) in blood depend not only on environmental contamination; but also numerous biotic factors are suspected to modulate concentrations: gender, diet, age, pregnancy, lactation and weaning (Debier et al., 2006). The objective of the present study was to investigate the occurrence and distribution of PCBs, PBDEs, their hydroxylated metabolites (HO-PCBs and HOPBDEs), HCB and DDTs ( $p, p^{\prime}$-DDE, $p, p^{\prime}$-DDT and $p, p^{\prime}$-DDD) in blood of free-ranging harbour seals, harbour porpoises held in captivity and a stranded harbour porpoise in order to elucidate the metabolism of these compounds. Several factors including species, age class, gender and year of sampling were apprehended to get further understanding of PCB and PBDE kinetic in harbour seals and harbour porpoises.

\section{Materials and methods}

\subsection{Samples, chemicals and target compounds}

Serum samples of 21 harbour porpoises in captivity from 20062008 were provided by SOS Dolfijn, Dolfinarium Harderwijk (The Netherlands), and were taken for regular medical purposes from the tail fluke. Information about the medical situation of these animals at the time of sampling can be found in Table 1 . Serum was isolated by centrifugation at 4000 rpm during 15 min (Hettich EBA-20) and kept
Table 1

Medical information of the harbour porpoises, held in captivity during rehabilitation, at the time of sampling.

\begin{tabular}{|c|c|c|c|c|c|c|}
\hline Code & $\begin{array}{l}\text { Days in } \\
\text { rehabilitation }\end{array}$ & Gender & $\begin{array}{l}\text { Estimated } \\
\text { age at time } \\
\text { of sampling } \\
\text { (years) }\end{array}$ & $\begin{array}{l}\text { Length } \\
(\mathrm{cm})\end{array}$ & $\begin{array}{l}\text { Weight } \\
(\mathrm{kg})\end{array}$ & $\begin{array}{l}\text { Condition at time } \\
\text { of sampling }\end{array}$ \\
\hline$\overline{\mathrm{P} 1}$ & 3247 & $\mathrm{M}$ & 9 & 132.5 & 40.25 & Healthy \\
\hline P2 & 1946 & M & 6 & 120 & 29.55 & $\begin{array}{l}\text { Slightly anaemic } \\
\text { due to blood loss } \\
\text { associated with a } \\
\text { urogenital lesion/ } \\
\text { inflammation }\end{array}$ \\
\hline P3 & 571 & $\mathrm{~F}$ & 2 & 140 & 35.8 & Healthy \\
\hline P4 & 117 & M & 1 & 116.5 & 27.8 & Healthy \\
\hline P5 & 0 & M & Adult & 145 & 44 & \\
\hline P6 & 5 & M & Adult & 149 & 42.3 & $\begin{array}{l}\text { Sample on day of } \\
\text { death, very severe } \\
\text { inflammatory } \\
\text { reaction probably } \\
\text { due to pneumonia }\end{array}$ \\
\hline P7 & 434 & $\mathrm{~F}$ & 2 & 126 & 38.05 & Anaemic \\
\hline P8 & 37 & $\mathrm{~F}$ & 1 & 113 & 26.46 & $\begin{array}{l}\text { Healthy, on } \\
\text { antibiotics after } \\
\text { recent stranding }\end{array}$ \\
\hline P9 & 0 & M & Adult & 142 & 41.3 & $\begin{array}{l}\text { Sample shortly } \\
\text { after stranding, } \\
\text { inflammatory } \\
\text { reaction in blood }\end{array}$ \\
\hline P10 & 128 & $\mathrm{~F}$ & 1 & 122 & 29.9 & $\begin{array}{l}\text { Healthy (animal } \\
\text { at the end of } \\
\text { treatment with } \\
\text { antibiotics) }\end{array}$ \\
\hline P11 & 42 & M & 1 & $110-114$ & 22.85 & $\begin{array}{l}\text { Severe anaemia } \\
\text { and inflammation }\end{array}$ \\
\hline P12 & 9 & $\mathrm{~F}$ & 1 & 118 & 19.6 & $\begin{array}{l}\text { Pneumonia, sepsis } \\
\text { and gastric impaction, } \\
\text { emaciation }\end{array}$ \\
\hline P13 & 7 & $\mathrm{~F}$ & Adult & 146 & 48.8 & $\begin{array}{l}\text { Anaemic and } \\
\text { pregnant. Animal } \\
\text { dies a month later } \\
\text { due to acute } \\
\text { hepatic lipidosis }\end{array}$ \\
\hline P14 & 30 & M & 1 & $108-112.5$ & 22.25 & $\begin{array}{l}\text { Severe anaemia, } \\
\text { antiparasitic } \\
\text { treatment }\end{array}$ \\
\hline P15 & 174 & $\mathrm{~F}$ & 2 & 136 & 34 & $\begin{array}{l}\text { Healthy (animal at } \\
\text { the end of treatment) }\end{array}$ \\
\hline P16 & 355 & $\mathrm{~F}$ & 3 & $133-134.5$ & 39.04 & Healthy \\
\hline P17 & 34 & M & 2 & $117-123$ & 26.15 & Laryngitis \\
\hline P18 & 183 & $\mathrm{~F}$ & 1 & 105 & 29.24 & $\begin{array}{l}\text { Anaemic due to } \\
\text { lungworm infection } \\
\text { (at time of sampling } \\
\text { only on antibiotics } \\
\text { after lungworm } \\
\text { treatment) }\end{array}$ \\
\hline P19 & 1 & M & 2 & 116 & 29.55 & Healthy \\
\hline P20 & 77 & $\mathrm{~F}$ & 1 & 108.5 & 26.95 & $\begin{array}{l}\text { Chronic hepatitis of } \\
\text { unclear significance }\end{array}$ \\
\hline P21 & 32 & $\mathrm{~F}$ & 2 & 116 & 27.2 & Healthy \\
\hline
\end{tabular}

at $-20{ }^{\circ} \mathrm{C}$ until further analysis. A serum sample of an adult harbour porpoise, stranded on the North Sea coast in 2003 was also analyzed. Serum samples of free-ranging harbour seals were collected from 47 animals caught in the frame of monitoring programs for the health assessment organized on Helgoland and Lorenzenplate (North Sea, Germany) in 2006-2008 and in Rømø (Denmark) in 2008. Seals were physically restrained and blood was drawn from the extradural venous sinus into sterile evacuated blood collection tubes (serum tubes Monovette ${ }^{\circledR}$, Germany) and kept at $-20^{\circ} \mathrm{C}$. Serum was isolated by centrifugation at $1500 \mathrm{~g}$ during $20 \mathrm{~min}$ at $20^{\circ} \mathrm{C}$ (Multifuge 3S-R, Kendro) (Hasselmeier et al., 2008).

In all samples, target compounds were PCBs (IUPAC-numbers: 52, $74,95,99,101,105,110,118,128,138,149,153,156,170,180,183,187$, 
194, 199), PBDEs (IUPAC-numbers: 28, 47, 99, 100, 153, 154), HCB, and pesticides ( $p, p^{\prime}$-DDE, $p, p^{\prime}$-DDT and $p, p^{\prime}$-DDD). The following $22 \mathrm{HO}-$ PCB congeners were investigated: 3-HO-CBs (numbers 118, 153, 138 and 180), 4-HO-CBs (numbers 79, 120, 107, 146, 127, 130, 163, 187, 162, 202, 177, 172, 193, 198, 199 and 208), and 4,4'-diHO-CB 202. The following 8 HO-PBDEs were also targeted: 2'-HO-BDE 68, 3-HO-BDE 47, 5-HO-BDE 47, 6-HO-BDE 47, 4-HO-BDE 42, 4'-HO-BDE 49, 6-HOBDE 99 and 4-HO-BDE 90. Standards were from Accustandard (HOPBDEs) or from Wellington Laboratories (HO-PCBs).

\subsection{Sample preparation}

The method for serum analysis was adapted from the methods described by Covaci and Voorspoels (2005) for the determination of neutral compounds in serum and by Weiss et al. (2006) for the determination of phenolic compounds. An accurate volume of serum (typically $1.5 \mathrm{ml}$ ) was spiked with internal standards (CB 143 and BDE 77 for neutrals and $4^{\prime}$-HO-CB 159 for phenolics), diluted 1:1 with Milli Q water, mixed with formic acid, sonicated for $20 \mathrm{~min}$ and extracted using solid-phase extraction (SPE) cartridges ( $6 \mathrm{ml} / 500 \mathrm{mg}$ Oasis HLB, Waters). Elution was done by $10 \mathrm{ml}$ of $\mathrm{MeOH}: \mathrm{DCM}(1: 1, v / v)$. After evaporation to near dryness, the analytes were reconstituted in $500 \mu \mathrm{l}$ hexane:DCM $(1: 1, v / v)$ and fractionated on silica SPE cartridges $(3 \mathrm{ml} /$ $500 \mathrm{mg}$, Varian). A first fraction containing PCBs and PBDEs was eluted with $5 \mathrm{ml}$ hexane, while the phenolic compounds were eluted with $6 \mathrm{ml} \mathrm{MeOH}$ :DCM $(1: 1, v / v)$. Both fractions were evaporated to dryness.

The first fraction (neutrals) was cleaned-up on $500 \mathrm{mg}$ acid silica $(44 \%, w / w)$ and the analytes were eluted with $8 \mathrm{ml}$ hexane:DCM $(1: 1$, $v / v)$. The cleaned extract was evaporated to dryness under a gentle nitrogen stream and reconstituted in $100 \mu \mathrm{l}$ iso-octane. The second fraction (phenolics) was derivatized for $30 \mathrm{~min}$ with diazomethane when MeO-PCBs and MeO-PBDEs were formed. After solvent evaporation, the dried residue was reconstituted in $200 \mu \mathrm{l}$ DCM and further cleaned-up on $500 \mathrm{mg}$ acid silica $(25 \%, w / w)$. Methoxylated compounds were eluted with $10 \mathrm{ml}$ hexane:DCM $(1: 1, v / v)$, the extract was evaporated to dryness under a gentle nitrogen stream and reconstituted in $100 \mu$ iso-octane.

\subsection{Analysis}

For the analysis of methoxylated derivatives and of PBDEs, a GCMS operated in electron capture negative ionisation (ECNI) mode was equipped with a $30 \mathrm{~m} \times 0.25 \mathrm{~mm} \times 0.25 \mu \mathrm{m}$ DB- 5 capillary column (J\&W Scientific). The ion source temperature was $170{ }^{\circ} \mathrm{C}$. The MS was used in the SIM mode with two ions monitored for each MeO-PCB congener in specific windows, while ions $m / z=79$ and 81 were monitored for MeO-PBDEs and for PBDEs during the entire run. Two $\mu \mathrm{l}$ of the extract was injected in cold pulsed splitless mode, splitless time $1.50 \mathrm{~min}$. Helium was used at constant flow $(1.0 \mathrm{ml} / \mathrm{min})$.

For the PCB, HCB and DDT ( $p, p^{\prime}$-DDT, $p, p^{\prime}$-DDE and $p, p^{\prime}$-DDD) analysis, a GC-MS operated in electron impact ionisation (EI) mode was equipped with a $25 \mathrm{~m} \times 0.22 \mathrm{~mm} \times 0.25 \mu \mathrm{m}$ HT- 8 capillary column (SGE). The ion source temperature was $230{ }^{\circ} \mathrm{C}$. The MS was used in the SIM mode with two ions monitored for each PCB homologue group in specific windows. Two $\mu$ l of the extract was injected in cold pulsed splitless mode, splitless time $1.50 \mathrm{~min}$. Helium was used at constant flow $(1.0 \mathrm{ml} / \mathrm{min})$.

\subsection{Quality Assurance/Quality Control (QA/QC)}

Multi-level calibration curves $\left(r^{2}>0.999\right)$ in the linear response interval of the detector were created for the quantification. QC was performed by regular analyses of procedural blanks, by random injection of standards, spiked samples and solvent blanks. The Quality Control scheme is also assessed through regular participation to interlaboratory comparison exercises organized by AMAP (POPs in serum). Obtained values were deviating no more than $20 \%$ from the consensus values. The mean recovery of internal standard $4^{\prime}-\mathrm{HO}-\mathrm{CB} 159$ in serum was $96 \pm 2 \%$. Recoveries assessed through spiking experiments at 25 and $125 \mathrm{pg} / \mathrm{ml}$ ranged between 90 and $93 \%$ with precision (RSD) $<2 \%$. For analytes detected in the procedural blanks, the mean procedural blank value was used for subtraction. After blank subtraction, the limit of quantification (LOQ) was set at 3 times the standard deviation of the procedural blank. For analytes that were not detected in the procedural blanks (all HOPCBs and HO-PBDEs), LOQs were calculated for $\mathrm{S} / \mathrm{N}=10$.

\subsection{Statistical analysis}

Statistical analyses were conducted using SAS 9.2 for Windows (SAS Institute Inc., Cary, NC, USA). Data were log-transformed and a value $1 / 2$ LOQ was used for concentrations below LOQ. Outliers were

Table 2

Medians and range (minimum-maximum) in $\mathrm{pg} / \mathrm{ml}$ of all compounds measured in the present study in serum of harbour seals and harbour porpoises.

\begin{tabular}{|c|c|c|}
\hline & Harbour seals & Harbour porpoises \\
\hline$N$ & $\overline{47}$ & $\overline{19}$ \\
\hline CB 52 & $180(<40-689)$ & $759(471-6040)$ \\
\hline CB 74 & $89(<40-333)$ & $332(123-711)$ \\
\hline CB 95 & $47(<30-178)$ & $889(535-6330)$ \\
\hline СВ 99 & $1970(456-8490)$ & $1030(503-9360)$ \\
\hline CB 101 & $523(173-1960)$ & $1280(606-2890)$ \\
\hline СВ 105 & $60(<30-160)$ & $199(119-564)$ \\
\hline CВ 110 & $<30(<30-111)$ & $144(<30-288)$ \\
\hline CB 118 & $250(73-689)$ & $1200(786-2900)$ \\
\hline CB 128 & $1170(256-5020)$ & $610(254-1510)$ \\
\hline CB 138 & $7670(1700-34,200)$ & $3390(1770-25,300)$ \\
\hline CB 149 & 830 (327-3870) & $2960(1670-17,600)$ \\
\hline CB 153 & $16,000(2930-79,800)$ & $6880(3330-51,300)$ \\
\hline CB 156 & $175(<20-622)$ & $<20$ \\
\hline CB 170 & $1230(200-8110)$ & $428(175-2690)$ \\
\hline СВ 180 & $3890(626-22,400)$ & $1400(703-8190)$ \\
\hline CB 183 & $720(127-3890)$ & 399 (206-2520) \\
\hline CB 187 & $4030(1047-19,000)$ & $1820(889-12,200)$ \\
\hline CB 194 & $307(67-2310)$ & $173(93-754)$ \\
\hline CВ 199 & $353(60-2380)$ & $266(126-1110)$ \\
\hline BDE 28 & $<10$ & $14(<10-33)$ \\
\hline BDE 47 & $59(11-348)$ & $668(271-1670)$ \\
\hline BDE 99 & $<10(<10-35)$ & $155(29-352)$ \\
\hline BDE 100 & $57(11-315)$ & $334(116-710)$ \\
\hline BDE 153 & $<10(<10-57)$ & $31(10-413)$ \\
\hline BDE 154 & $<10(<10-21)$ & $78(16-766)$ \\
\hline 4-НО-СВ 79 & $147(<20-467)$ & $<20$ \\
\hline 4-HO-СВ 107 & $1840(301-6440)$ & $<20(<20-28)$ \\
\hline 3-НО-СВ 118 & $<20$ & $<20$ \\
\hline 4-HO-СВ 120 & $69(<20-241)$ & $<20$ \\
\hline 4-HO-СВ 127 & $<15(<15-15)$ & $<15$ \\
\hline 4-HO-СВ 130 & $66(<15-474)$ & $<15(<15-19)$ \\
\hline 3-HO-СВ 138 & $117(16-529)$ & $<15$ \\
\hline 4-HO-СВ 146 & $491(108-2340)$ & $<15$ \\
\hline 3-НО-СВ 153 & $24(<15-101)$ & $<15$ \\
\hline 4-HO-СВ 162 & 657 (191-1940) & $<10$ \\
\hline 4-HO-СВ 163 & 169 (25-985) & $<10$ \\
\hline 4-HO-СВ 172 & $22(<10-136)$ & $<10$ \\
\hline 4-HO-СВ 177 & $151(31-697)$ & $<10$ \\
\hline 3-HO-СВ 180 & $<10(<10-32)$ & $<10$ \\
\hline 4-HO-СВ 187 & $253(96-870)$ & $<10$ \\
\hline 4-НО-СВ 193 & $16(<10-56)$ & $<10$ \\
\hline 4-HO-СВ 198 & $12(<10-56)$ & $<10$ \\
\hline 4-НО-СВ 199 & $<10(<10-28)$ & $<10$ \\
\hline 4-HO-СВ 202 & $257(87-695)$ & $<10$ \\
\hline 4-diHO-CB 202 & $<10(<10-11)$ & $<10$ \\
\hline 4-HO-СВ 208 & $64(23-200)$ & $<10$ \\
\hline $\mathrm{HCB}$ & $<20$ & $641(343-1650)$ \\
\hline$p, p^{\prime}-\mathrm{DDE}$ & $2750(722-8440)$ & $3860(1590-15,600)$ \\
\hline$p, p^{\prime}-\mathrm{DDD}$ & $<50(<50-107)$ & 636 (269-3320) \\
\hline$p, p^{\prime}-\mathrm{DDT}$ & $213(<50-678)$ & $510(197-2330)$ \\
\hline 6-MeO-BDE 47 & $<10$ & $195(100-732)$ \\
\hline 2'-MeO-BDE 68 & $<10$ & $34(10-95)$ \\
\hline
\end{tabular}



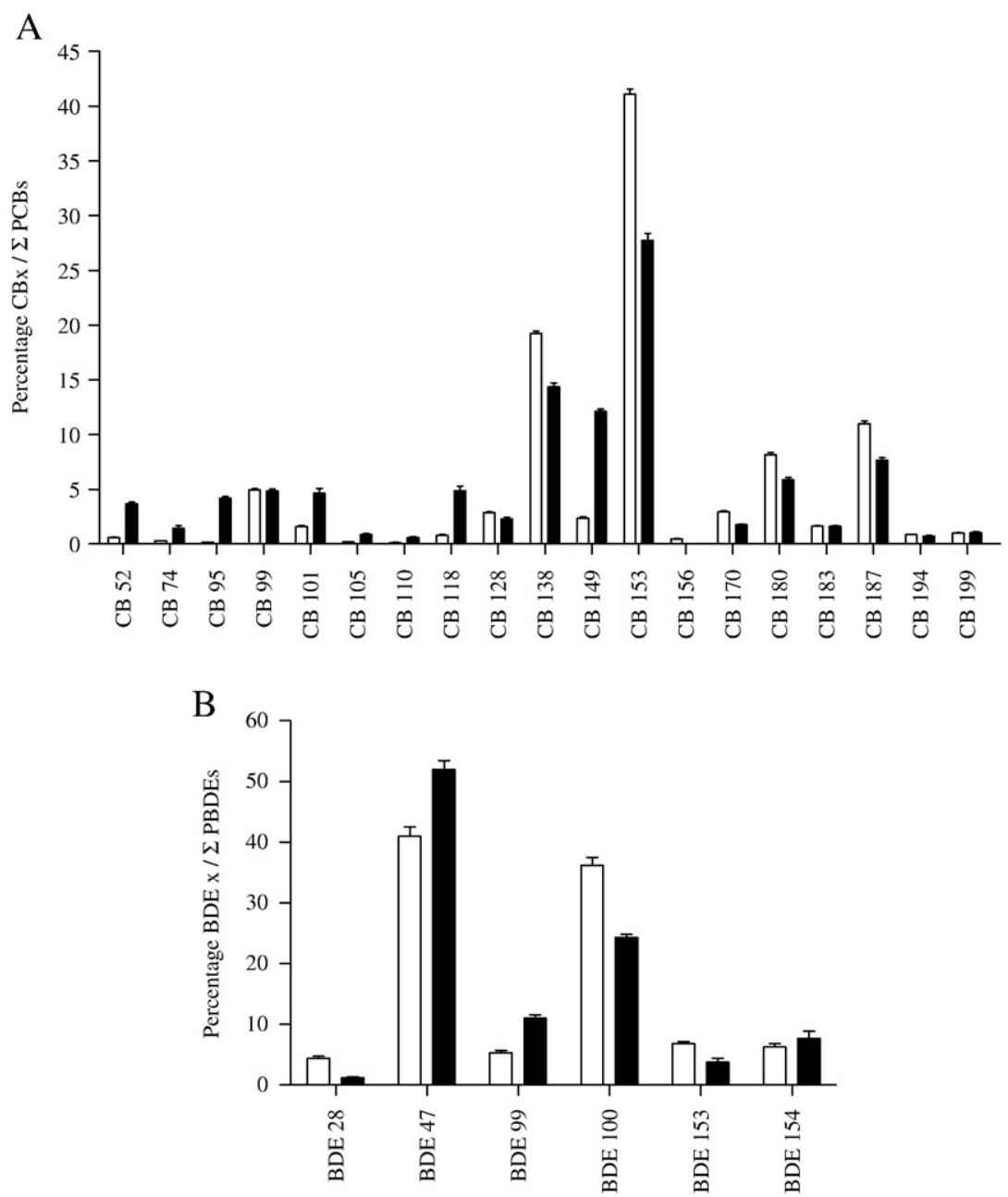

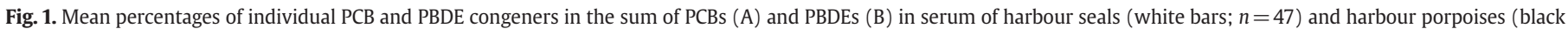
bars; $n=19$ ). Error bars represent standard errors (SE).

detected using boxplots and were removed for further statistical analysis. The influence of age, gender, location (only for harbour seals) and year of sampling was investigated with a two-way ANOVA test followed by a Tukey's post hoc test. Age (juvenile-J and Adult-A) and gender (Male-M and Female-F) were used as fixed variables, location (Germany-G and Denmark-D) and year of sampling (2006, 2007 and 2008) as random variables. The level of statistical significance was defined at $p<0.05$.

\section{Results}

Median values and ranges (minimum and maximum) of all compounds measured in this study in serum of harbour seals and harbour porpoises are presented in Table 2.

3.1. Levels and profiles in harbour seals

BDE 28 and HCB were not detected in any investigated sample, while $p, p^{\prime}$-DDD and congeners CB 110, BDE 99, BDE 154 and BDE 153 were found in less than 50\% of all samples.

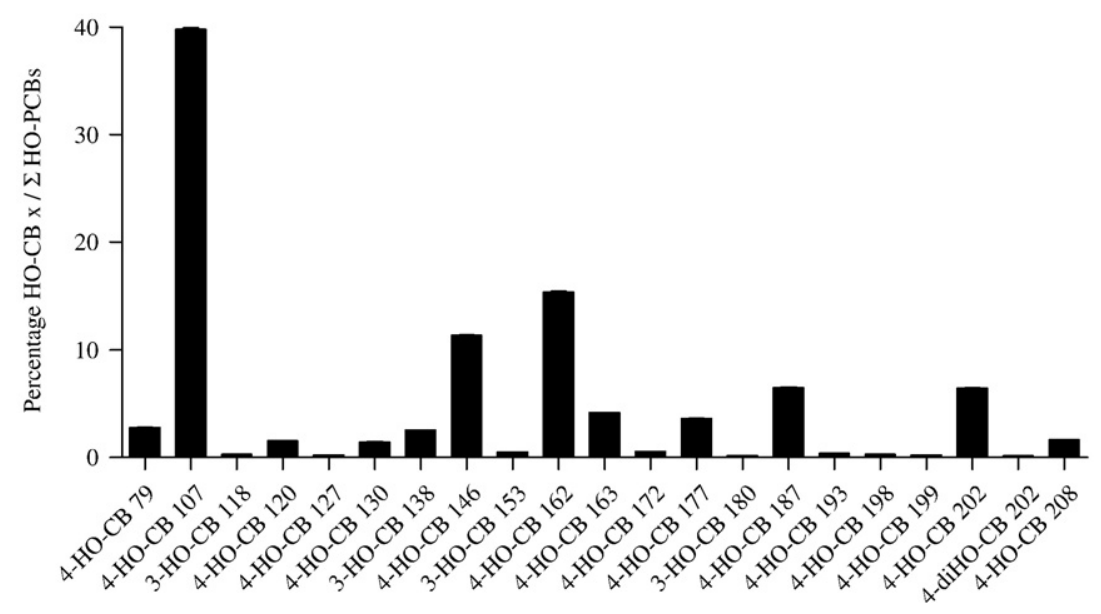

Fig. 2. Mean percentages of HO-PCB congeners in sum of HO-PCBs in serum of harbour seals. Error bars represent standard errors (SE). 


\begin{tabular}{|c|c|c|}
\hline \multirow{2}{*}{ HO-compounds } & \multicolumn{2}{|c|}{ PCB precursors } \\
\cline { 2 - 3 } & direct insertion & NIH-shift \\
\hline 4-HO-CB107 & CB 107 & CB 118, 105 \\
\hline 3-HO-CB118 & CB 118 & CB 107,126 \\
\hline 4-HO-CB120 & CB 120 & CB 118 \\
\hline 4-HO-CB130 & CB 130 & CB 128, 138 \\
\hline 3-HO-CB138 & CB 138 & CB 130, 157 \\
\hline 4-HO-CB146 & CB 146 & CB 138, 153 \\
\hline 3-HO-CB153 & CB 153 & CB 146, 128 \\
\hline 4-HO-CB172 & CB 172 & CB 170, 180 \\
\hline 3-HO-CB180 & CB 180 & CB 172 \\
\hline 4-HO-CB187 & CB 187 & CB 183 \\
\hline 4-HO-CB-199 & CB 199 & CB 204 \\
\hline 4-HO-CB202 & CB 202 & CB 199 \\
\hline 4,4'-diHO-CB202 & CB 202 $\left(^{*}\right)$ & CB 199 \\
\hline
\end{tabular}

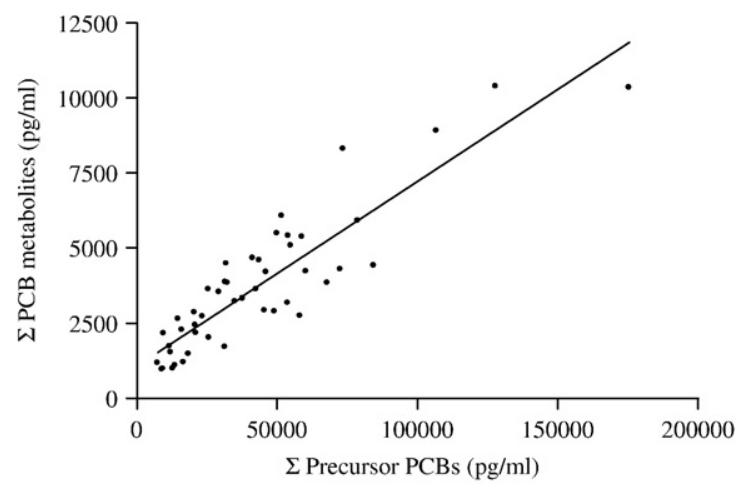

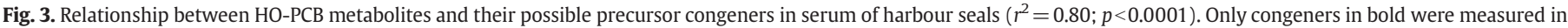
the present study and were therefore included in the calculations. The table was made according to Jaspers et al. (2008). (*) Double insertion.

In general, values of sum PCBs were more than 200 times higher compared to concentrations of sum PBDEs and about 15 times higher than concentrations of the sum DDTs (sum of $p, p^{\prime}$-DDT, $p, p^{\prime}$-DDE and $p, p^{\prime}$-DDD). Values ranged from $9180 \mathrm{pg} / \mathrm{ml}$ to $194000 \mathrm{pg} / \mathrm{ml}$ for sum PCBs, $772 \mathrm{pg} / \mathrm{ml}$ to $9140 \mathrm{pg} / \mathrm{ml}$ for the sum DDTs and $37 \mathrm{pg} / \mathrm{ml}$ to $726 \mathrm{pg} / \mathrm{ml}$ for sum PBDEs. For PCBs, CB 153 was the predominant congener in all samples, followed by respectively CB 138, CB 187 and CB 180 (Fig.1A).p,p'-DDE was the most dominant pesticide, followed by $p, p^{\prime}$-DDT and $p, p^{\prime}$-DDD. For PBDEs, BDE 47 and BDE 100 were the most dominant congeners. Other congeners, such as BDE 99, BDE 153 and BDE 154 (Fig. 1B), were of reduced importance. HCB was not detected in any serum sample in the present study.

No HO-PBDEs were found in any serum sample of harbour seals in the present study. Some HO-PCBs (3-HO-CB 118 and 4-HO-CB 127) were not found in any sample, while 4-HO-CB 199, 3-HO-CB 180 and 4,4'-diHO-CB 202 were detected in less than 50\% of all samples. The highest concentrations were found for 4-HO-CB 107, a lower chlorinated compound, while higher chlorinated compounds showed lower values (Fig. 2). In all individuals, 4-HO-CB 107 was followed by 4-HO-CB 162 and 4-HO-CB 146.

When divided into 4 groups (AM-adult males, JM-juvenile males, JF-juvenile females and AF-adult females), distribution patterns of sum PBCs and sum HO-PCBs were $A M>J M, J F>A F$. Patterns of sum PBDEs and sum DDTs were JM, JF $>A M>A F$ suggesting that AM have better developed metabolic capacities than juveniles. Unfortunately, differences between the age-gender groups were too small to be statistically significant (all $p>0.05$ ). Location and year of sampling were not important for sum PCBs and sum DDTs, while only the year of sampling had a minor effect on concentrations of sum HO-PCBs and of sum PBDEs. For these latter two, the highest concentrations of sum HO-PCBs and sum PBDEs were found in 2006 followed by 2008 and 2007, respectively. However, these differences were considered to be a consequence of the different sample sizes ( $n=21,10$ and 16 for 2006, 2007 and 2008 respectively).
In general, levels of sum PCBs were approximately 11 times higher than levels of their metabolites (ratio $\Sigma$ HO-PCBs $/ \Sigma P C B s=0.086$ ). In this study, a good correlation $\left(r^{2}=0.80 ; p<0.0001\right)$ was found between the sum of HO-PCBs and their possible precursor congeners (Fig. 3 ).

\subsection{Levels and profiles in harbour porpoises}

CB 156 was found in less than 50\% of all samples. The levels of sum PCBs (range: $13,300-148,300 \mathrm{pg} / \mathrm{ml}$ ) were higher than sum DDTs (range: $2150-20,900 \mathrm{pg} / \mathrm{ml}$ ) followed by sum PBDEs (range: $495-2900 \mathrm{pg} / \mathrm{ml}$ ) and HCB (range: $343-1650 \mathrm{pg} / \mathrm{ml}$ ). In general, $\mathrm{PCB}$ and PBDE profiles were: CB $153>$ CB $138>$ CB $149>$ CB $187>$ CB 180 for PCBs and BDE $47>$ BDE $100>$ BDE 99 $>$ BDE $154>$ BDE 153 for PBDEs (Fig. 1 A and B).p, $p^{\prime}$-DDE was the most dominant compound among the DDTs, followed by $p, p^{\prime}$-DDD and $p, p^{\prime}$-DDT.

Only 4-HO-CB 107 and 4-HO-CB 130 could be measured in serum samples of harbour porpoises at very low levels and in a limited number of samples (4 and 1 sample, respectively). No other HO-PCBs or HO-PBDEs were found in any serum sample of harbour porpoises in the present study.

The only AF harbour porpoise analyzed in this study was pregnant at the time of sampling (animal P13, Table 1) and had very low concentrations of sum PCBs, sum PBDEs, HCB and sum DDTs compared to all other individuals. Also, there was an outlier in the JF-group with concentrations 10-20 times higher than the average of the JF-group (animal P12, Table 1). Both samples were excluded from statistical analysis and further calculations (see further). In all other samples (AM, JM and JF), no significant effects of age, gender or time of sampling were found on concentrations of sum PCBs, sum PBDEs, sum DDTs and HCB. For all these compounds, AM had higher concentrations (although not significant) compared to the juveniles.

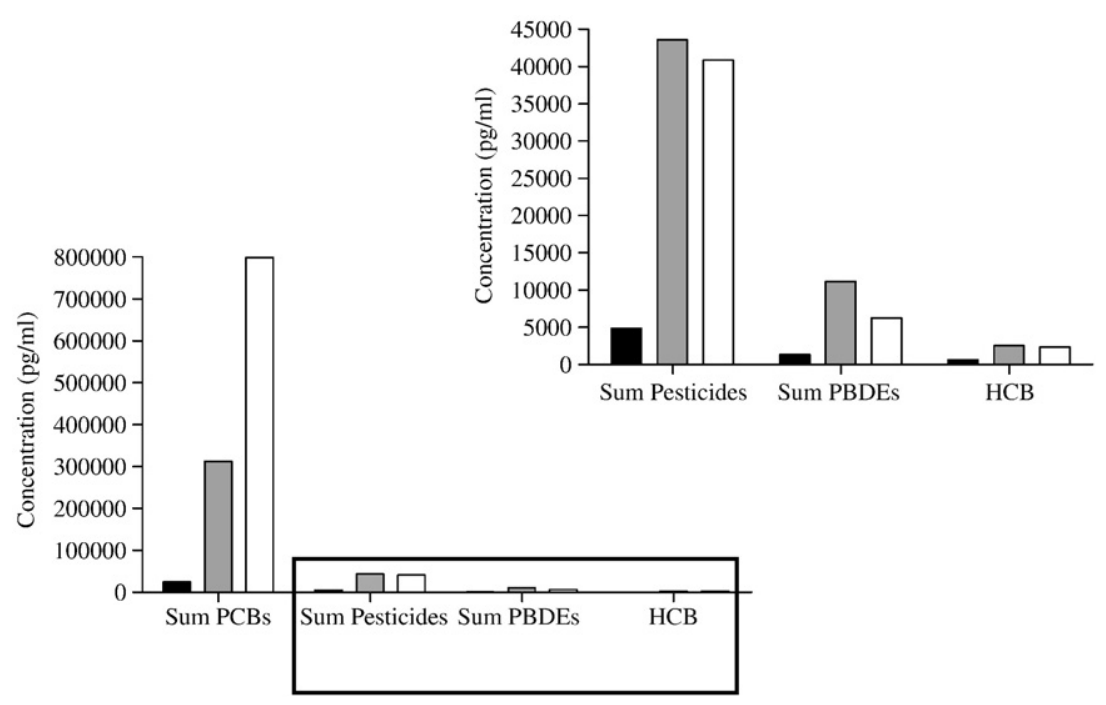

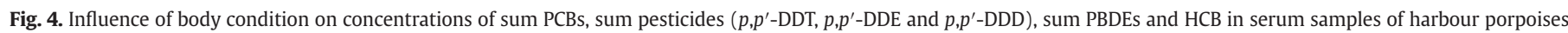
( $\mathbf{\square}=$ median of harbour porpoises in captivity $(n=19)$, $\square=$ concentrations in serum of the outlier in the JF-group, $\square=$ concentrations in serum of the wild adult male). 
In addition to the 21 harbour porpoises in captivity, serum of a wild adult male harbour porpoise (stranded at the Belgian coast in 2003) was also analyzed. This animal was emaciated and necropsy revealed lung pneumonia. The outlier in the JF-group (animal P12, Table 1), which was excluded from further statistical analysis as mentioned earlier, was also emaciated. Both animals have concentrations for sum PCBs, sum PBDEs, HCB and sum DDTs that exceed by far the median values of the harbour porpoises in captivity (Fig. 4).

3.4. Naturally-produced MeO-PBDEs in harbour seals and harbour porpoises

Two naturally-produced MeO-PBDEs, 2'-MeO-BDE 68 and 6-MeO-BDE 47, were analyzed as well. Both compounds were not detected in any serum sample of the harbour seals. In harbour porpoises, no influence of age, gender and location of sampling was found and a median concentration of $221 \mathrm{pg} / \mathrm{ml}$ with 6-MeO-BDE 47 accounting for more than $84 \%$ of the total sum of MeO-PBDEs was calculated.

\section{Discussion}

This is the first study to report the simultaneous measurement of PCBs, PBDEs, HO-PCBs, HO-PBDEs, DDTs and naturally-produced MeOPBDEs in blood of living harbour seals and harbour porpoises from the North Sea.

\subsection{Levels}

Information on the levels of PBDEs and HO-PCBs in blood of marine mammals is scarce. A comparison with results from other areas is complicated because contaminants are reported in other tissues than serum (e.g. liver, adipose tissue), because concentrations are expressed in different ways $(\mathrm{pg} / \mathrm{ml}, \mathrm{pg} / \mathrm{g}$ wet weight (ww), $\mathrm{pg} / \mathrm{g}$ lipid weight (lw)) and because not always the same congeners are analyzed. Concentrations of PCBs in serum of harbour seals in the present study (sum of 19 congeners) were approximately 3 to 6 times higher than concentrations of Scottish adult grey seal (Halichoerus grypus) females in late lactation when lipid mobilization is highest (sum of 26 congeners; Debier et al., 2003a). Levels of PCBs are also higher than the concentrations reported in whole blood of ringed seals (Phoca hispida) and bearded seals (Erignathus barbatus) from Svalbard (sum of 33 congeners; Bang et al., 2001) and in whole blood of harbour seals from California (sum of 20 congeners; Young et al., 1998). In an experiment where harbour seals were fed fish from a contaminated area, the Baltic Sea, blood (fraction III containing mostly high density particles) concentrations of PCBs were associated with immune disorders and reproductive impairment (Boon et al., 1987). Since the results from the present study are more than an order of magnitude higher compared to these results, serious concerns have been raised about the health condition of the harbour seals in the North Sea at this moment. It is difficult to discuss differences in levels in serum between harbour seals and harbour porpoises, since it is unknown how (and if) living in captivity for a few months affects the contaminant concentrations. Although several PCBs and PBDEs are stable and persistent in marine mammals and the porpoises in rehabilitation from the present study received amounts of fish caught in the North Sea, it remains unclear how captivity may influence the concentrations of these pollutants. A number of 7 out of 20 (the emaciated animal excluded) porpoises were healthy at the time of sampling, while the other 13 were ill in some way (Table 1). Yet, no part of the individual variation could be assigned to the health status. Concentrations of PCBs in harbour porpoises are in general somewhat lower compared to the concentrations found in harbour seals, but still exceed the levels mentioned above in other marine mammal species.

\subsection{Patterns}

Profiles of PCBs and DDTs in serum of harbour seals were similar to the patterns found in whole blood samples (Young et al., 1998) and in blubber or liver (Kajiwara et al., 2001; Shaw et al., 2005; Weijs et al., 2009a), suggesting that the contaminant's profiles are well conserved in this species, regardless of the tissue (Hutchinson and Simmonds, 1994; Vetter et al., 1996; Boon et al., 1997). For PBDEs, patterns in blood differed from patterns in blubber (Shaw et al., 2007; Weijs et al., 2009a) probably due to a selective retention of some congeners in other tissues than blood. HCB was not detected in any serum sample but seems to be a minor contaminant in blubber of several other pinnipeds from other areas as well (Ruus et al., 1999; Kajiwara et al., 2001; Hobbs et al., 2002; Shaw et al., 2005). Formation of PCB metabolites may occur via direct insertion and/or NIH shift (Letcher et al., 2000). Since HO-PCBs were not detected in liver of fish species caught in the North Sea in 2008 (Covaci, unpublished data), concentrations found in harbour seal serum are most probably the result of intrinsic metabolic breakdown of PCBs into HO-PCBs in the marine mammals. $\Sigma$ HO-PCBs/ $\Sigma$ PCBs ratios smaller than 1 were also found for bottlenose dolphins (Tursiops truncatus) from the Indian River Lagoon (Florida, USA) and Charleston (Montie et al., 2008), for ringed seals from Québec, Canada (Sandau et al., 2000) and for bowhead whales (Balaena mysticetus) from Alaska (Hoekstra et al., 2003). In contrary, ratios greater than 1 were detected in blood of polar bears (Ursus maritimus) from Canada (Sandau et al., 2000) and Greenland (Sandala et al., 2004; Gebbink et al., 2008) as a result of a high capacity to form HO-PCBs (Table 3 ). The pattern found in the present study was dominated by 4-HO-CB 107 followed by 4-HO-CB 162 and 4-HO-CB 146. Although these results agree well with results from Løken et al. (2008), they are different from patterns reported in liver, brain, blood and adipose tissue of polar bears (Sandala et al., 2004; Gebbink et al., 2008), in plasma of bowhead whales (Hoekstra et al., 2003) and in bottlenose dolphins (Montie et al., 2008).

PCBs can be divided into several metabolic groups according to their structure and affinity for Phase 1 cytochrome P450 enzyme subgroups. Different patterns are therefore caused by the presence and activity of these enzyme subgroups and are considered to be species specific. Meijer et al. (2008) measured HO-PCBs in maternal and cord serum of humans and concluded that HO-PCBs can be transferred to the offspring. Debier et al. (2003a) found that young animals have a lower ability to detoxify contaminants compared to adults because their metabolism is primarily focused on their growth and overall development. As a consequence, regardless of their metabolic capacities, young animals are probably exposed to HO-PCBs and may experience the possible effects of these compounds as well.

The PCB, PBDE and pesticide patterns found in serum of harbour porpoises agree well with profiles found in liver and blubber (Covaci et al., 2002; Weijs et al., 2009a) and seem also to be highly species

\section{Table 3}

Means and standard deviations (SD) of the concentrations (ng/g wet weight) of HO$\mathrm{PCBs}$ in tissues of four marine species.

\begin{tabular}{llllcl}
\hline Species & $n$ & Mean \pm SD & Tissue & HO-PCB/PCB & Reference \\
\hline Bowhead whales & 10 & $1.52 \pm 0.31^{\mathrm{a}}$ & Plasma & 0.547 & Hoekstra et al. (2003) \\
Bottlenose dolphins & 10 & $3.9 \pm 3.2$ & Plasma & 0.016 & Houde et al. (2006) \\
& 42 & $18 \pm 21$ & Plasma & 0.082 & \\
& 32 & $209 \pm 211$ & Plasma & 0.679 & \\
& 5 & $94 \pm 103$ & Plasma & 0.470 & \\
& 12 & $33 \pm 21$ & Plasma & 0.236 & \\
Polar bears & 35 & $64 \pm 53$ & Plasma & 0.435 & \\
& 21 & $168 \pm 110$ & Plasma & 0.644 & \\
& 20 & $60 \pm 8^{\mathrm{a}}$ & Adipose & 0.011 & Gebbink et al. (2008) \\
& & $1020 \pm 132^{\mathrm{a}}$ & Blood & 25.5 & \\
Harbour seals & & $18 \pm 3^{\mathrm{a}}$ & Brain & 0.122 & \\
& & $355 \pm 36^{\mathrm{a}}$ & Liver & 0.114 & \\
& 5 & $182.3 \pm 72.1$ & Blood & 8.30 & Sandala et al. (2004) \\
& & $2.49^{\mathrm{b}}$ & Liver & 0.009 & Løken et al. (2008) \\
& 47 & $4.35^{\mathrm{b}}$ & Plasma & 0.344 & \\
& & Serum & 0.086 & Present study \\
\hline
\end{tabular}

\footnotetext{
a Standard error or SE.

b Median values.

c Expressed in $\mathrm{ng} / \mathrm{ml}$.
} 
specific. In contrast to harbour seals, $\mathrm{HO}-\mathrm{PCBs}$ were only occasionally measured in serum of harbour porpoises. Houde et al. (2006) detected HO-PCBs in plasma of bottlenose dolphins, while Hoekstra et al. (2003) found HO-PCBs in plasma of bowhead whales. The difficulties of harbour porpoises to form HO-PCBs, can therefore not be extrapolated to other cetaceans.

When comparing harbour seals and harbour porpoises, it is very clear that the porpoises have difficulties in forming HO-PCBs and that they accumulate a higher number of $\mathrm{PCB}$ and PBDE congeners compared to the seals. Troisi et al. (2001) analyzed PCB and DDE methyl sulfones in lung and uterus of a cetacean (striped dolphins Stenella coeruleoalba) and a pinniped species (harbour seal) (all morbillivirus epizootic victims) and found higher concentrations of methyl sulfones in both tissues of harbour seals compared to striped dolphins. Further, it seems that harbour porpoises have only one possible way for metabolic breakdown of PCBs, namely formation of $\mathrm{MeSO}_{2}$-PCBs (Chu et al., 2003). In contrast, harbour seals can form HO-PCBs and $\mathrm{MeSO}_{2}$-PCBs and both metabolites to a greater extent than harbour porpoises. Both classes of PCB metabolites including the precursor PCBs are potential endocrine-disruptors and are associated with endocrine-related effects, such as cytotoxicity, competitive binding with several receptors and disruption of hormone homeostasis (Letcher et al., 2000; Sandala et al., 2004). So far, no classification regarding toxicity of PCBs, $\mathrm{HO}-\mathrm{PCBs}$ and $\mathrm{MeSO}_{2}$-PCBs is available. Therefore, it remains debatable whether metabolic transformation capacities can improve the overall health condition of an organism. Further toxicity tests with $\mathrm{PCBs}, \mathrm{HO}-\mathrm{PCBs}$ and $\mathrm{MeSO}_{2}-\mathrm{PCBs}$ are needed to assess and to compare the condition of harbour seals and harbour porpoises at this moment.

Although biotransformation of PBDEs in beluga whales (Delphinapterus leucas) was earlier shown to occur (McKinney et al., 2006a), no HOPBDEs were found in the investigated blood samples of harbour seals and harbour porpoises. This is a confirmation of the results of a recent study (Meijer et al., 2008), performed in blood of pregnant women and their infants in The Netherlands, which was also unable to detect a HOPBDE (6-HO-BDE 47). Moreover, no HO-PBDEs were found in ringed seal blubber and beluga whale blood and liver (Kelly et al., 2008). In contrast, detectable but not quantifiable HO-PBDE concentrations were reported in beluga whale livers (McKinney et al., 2006b) and very low yet measurable concentrations of 0.01 to $0.1 \mathrm{ng} / \mathrm{g}$ lipid equivalent were found in blubber and milk of beluga whales (Kelly et al., 2008). However, since concentrations of PBDEs in harbour seals are lower than levels in harbour porpoises, a greater capacity for debromination of PBDEs in harbour seals is assumed as previously shown for BDE 209 in grey seals (Thomas et al., 2005).

\subsection{Naturally-produced MeO-PBDEs}

Vetter (2006) raised the hypothesis that higher contributions of 2'-MeO-BDE 68 are caused by sponges or associated organisms, whereas higher proportions of 6-MeO-BDE 47 are an indication of the presence of algae or associated organisms. The dominance of 6-MeOBDE 47 in the present study was also found in blubber of minke whales (Balaenoptera acutorostrata) (Marsh et al., 2005), in male ringed seals and beluga whales (Kelly et al., 2008), in grey seals and ringed seals (Haglund et al.,1997) and in pre-industrial whale oil (Teuten and Reddy, 2007). Reversed patterns were found in blubber of striped dolphins (Marsh et al., 2005) and several marine mammal species from Oceania (Melcher et al., 2005) and Brazil (Dorneles et al., submitted for publication). A possible explanation for the presence of MeO-PBDEs only in harbour porpoises (21 porpoises in rehabilitation and the wild emaciated porpoise) in the present study might be that they feed on offshore prey coming within the southern part of the North Sea, while harbour seals feed more inshore as evidenced by their stable isotope signatures (Das et al., 2003; Weijs et al., 2009b). Higher concentrations of MeO-PBDEs in cetaceans in continental shelf and oceanic environ- ments compared to species from estuarine areas were also recently found in Brazilian waters (Dorneles et al., submitted for publication).

\subsection{Blood as biomonitoring tool}

In marine mammals, or in all mammals for that matter, the blood is responsible for the transport of all kinds of molecules, such as lipids and proteins, from one organ to the other inside the body. The concentrations of these molecules in blood however may change as a result of several factors like the feeding status, metabolism and the overall health condition of the animal. These factors are also important for explaining the variation of pollutants in blood due to the (high) lipophilic nature of, for example, PCBs, PBDEs and the affinity of HO-PCBs for proteins. To date, no information about the concentrations of pollutants before and after a meal in marine mammal blood is available. However, although the feeding status of the animals at the moment of blood sampling was unknown, it can not be ruled out for explaining the individual variation among the animals. It is impossible to discuss the influence of the other two factors, namely metabolism and health condition, without taking the role of blubber into account. In general, blubber has a double function. It provides insulation for the body (Dunkin et al., 2005) and it also stores energy in the form of lipids (Koopman et al., 1996; Kastelein et al., 1997). A depletion of the blubber, caused by seasonal changes in blubber thickness or more extreme cases such as emaciation or complete fasting during lactation, may lead to lipid mobilization throughout the body (Debier et al., 2003a,b; 2006), reflected in higher levels of lipids/lipophilic pollutants in the blood. Harbour seals and porpoises do not fast during lactation or other periods of their reproductive cycle (Burns, 2002), but have a seasonally variation in blubber thickness (Lockyer, 2007). In the present study however, for the harbour seals, sampling was only done once every year, making it impossible to compare between seasons of the same year. For the harbour porpoises, being in rehabilitation may suppress this seasonality. The very high concentrations found in serum of the two porpoises (one from a rehabilitation centre, one found stranded), both suffering from emaciation and lung pneumonia, were considered to be a reflection of the depletion of the blubber. These conditions, however, are more exceptional than general (Siebert et al., 2001) and can be seen relatively easy for harbour porpoises as these animals develop a 'neck' after a few days without feeding (Kastelein et al., 1997). So far, biomonitoring of PCBs and PBDEs was mainly done in blubber of marine mammals. As concentrations in blubber were found to be correlated with blubber thickness (Debier et al., 2003a; Montie et al., 2008; Weijs et al., 2009a), these results are equally dependent on the blubber thickness as concentrations in blood. It was not possible to correlate concentrations in blood to concentrations in blubber in the present study. In contrast to blubber, blood has the advantage that sampling can more easily occur in living animals which is always more realistic.

\section{Conclusions}

HO-PCBs are particularly bound to proteins, so that blood is the ideal substrate for detecting HO-PCBs. The presence of HO-PCBs in serum of harbour seals suggests that these animals are capable of metabolizing PCBs, while harbour porpoises are not. In general, higher numbers of compounds (PCBs, PBDEs, HCB, 2'-MeO-BDE 68, 6-MeOBDE 47 and DDTs) were detected in serum of harbour porpoises. Despite the fact that correlations between levels in serum and blubber, as storage compartment for the lipophilic compounds, could not be made, profiles of PCBs and PBDEs in serum were comparable with profiles in blubber. Within each species, variation between individuals remained limited, even without knowing the feeding status (time between feeding and sampling, amount of food ingested, etc.) of each individual and without taking the season of sampling into account. Concentrations in serum were assumed to be correlated with the body condition, in particular the emaciation, of the animals. 


\section{Acknowledgements}

SOS Dolfijn, Dolfinarium Harderwijk is greatly acknowledged for providing blood samples of harbour porpoises held in captivity during recovery. Blood samples of harbour seals were collected in the frame of the health monitoring of harbour seals funded by the National Park Agency of Schleswig-Holstein, Germany. The catches in Germany and Denmark were possible thanks to a lot of experienced helpers. Liesbeth Weijs is financially supported by the Institute for the Promotion of Innovation through Science and Technology in Flanders (IWT-Vlaanderen). Adrian Covaci is financially supported by a postdoctoral fellowship from the Research Scientific Foundation Flanders (FWO). Krishna Das is Research Associate at FRS-FNRS (Fonds pour la Recherche Scientifique).

\section{References}

Bang K, Jenssen BM, Lydersen C, Skaare JU. Organochlorine burdens in blood of ringed and bearded seals from north-western Svalbard. Chemosphere 2001;44:193-203.

Benedict RT, Stapleton HM, Letcher RJ, Mitchelmore CL. Debromination of polybrominated diphenyl ether-99 (BDE-99) in carp (Cyprinus carpio) microflora and microsomes. Chemosphere 2007;69:987-93.

Beineke A, Siebert U, McLachlan M, Bruhn R, Thron K, Failing K, et al. Investigations of the potential influence of environmental contaminants on the thymus and spleen of harbor porpoises (Phocoena phocoena). Environ Sci Technol 2005;39:3933-8.

Birnbaum LS, Staskal DF. Brominated flame retardants: cause for concern? Environ Health Perspect 2004;112:9-17.

Boon JP, Reijnders PJH, Dols J, Wensvoort P, Hillebrand MTJ. The kinetics of individual polychlorinated biphenyl congeners in female harbour seals (Phoca vitulina), with evidence for structure-related metabolism. Aquat Toxicol 1987;10:307-24.

Boon JP, van der Meer J, Allchin CR, Law RJ, Klungsoyr J, Leonards PEG, et al Concentration-dependent changes of $\mathrm{PCB}$ patterns in fish-eating mammals: structural evidence for induction of cytochrome P450. Arch Environ Contam Toxicol 1997;33:298-311.

Boon JP, Lewis WE, Tjoen-A-Choy MR, Allchin CR, Law RJ, de Boer J, et al. Levels of polybrominated diphenyl ether (PBDE) flame retardants in animals representing different trophic levels of the North Sea food web. Environ Sci Techno 2002;36:4025-32

Bossart GD. Emerging diseases in marine mammals: from dolphins to manatees. Microbe 2007;2:544-9.

Bruhn R, Kannan N, Petrick G, Schulz-Bull DE, Duinker JC. CB pattern in the harbour porpoise: bioaccumulation, metabolism and evidence for cytochrome P450 IIB activity. Chemosphere 1995;31:3721-32.

Burns JJ. Harbor seal and spotted seal Phoca vitulina and P. largha. In: Perrin WF, Würsig B, Thewissen JGM, editors. Encyclopedia of marine mammals, vol. 1. San Diego: Academic Press; 2002. p. 552-60.

Cheek AO, Kow K, Chen J, McLachlan JA. Potential mechanisms of thyroid disruption in humans: interaction of organochlorine compounds with thyroid receptor, transthyretin, and thyroid-binding globulin. Environ Health Perspect 1999;107:273-8.

Chu S, Covaci A, Haraguchi K, Voorspoels S, Van de Vijver K, Das K, et al. Levels and enantiomeric signatures of methyl sulfonyl PCB and DDE metabolites in livers of harbor porpoises (Phocoena phocoena) from the Southern North Sea. Environ Sci Technol 2003;37:4573-8.

Covaci A, Voorspoels S. Optimization of the determination of polybrominated diphenyl ethers in human serum using solid-phase extraction and gas chromatography-electron capture negative ionization mass spectrometry. J Chromatogr B 2005;827:216-23.

Covaci A, Van de Vijver K, De Coen W, Das K, Bouquegneau JM, Blust R, et al. Determination of organohalogenated contaminants in liver of harbour porpoises (Phocoena phocoena) stranded on the Belgian North Sea coast. Mar Pollut Bull 2002;44:1157-65.

Damstra T, Barlow S, Bergman Å, Kavlock R, Van Der Kraak G. Global assessment of the state-of-science of endocrine disruptors, International Programme on Chemica Safety. World Health Organization; 2002.

Das K, Lepoint G, Leroy Y, Bouquegneau JM. Marine mammals from the Southern North Sea: feeding ecology data from $\delta^{13} \mathrm{C}$ and $\delta^{15} \mathrm{~N}$ measurements. Mar Ecol Prog Ser $2003 \cdot 263: 287-98$

Das K, Vossen A, Tolley K, Vikingsson G, Thron K, Müller G, et al. Interfollicular fibrosis in the thyroid of the harbour porpoise: an endocrine disruption? Arch Environ Contam Toxicol 2006;51:720-9.

Debier C, Pomeroy PP, Dupont C, Joiris C, Comblin V, Le Boulengé E, et al. Quantitative dynamics of PCB transfer from mother to pup during lactation in UK grey seals, Halichoerus grypus. Mar Ecol Prog Ser 2003a;247:237-48.

Debier C, Pomeroy PP, Dupont C, Joiris C, Comblin V, Le Boulengé E, et al. Dynamics of PCB transfer from mother to pup during lactation in UK grey seals Halichoerus grypus: differences in PCB profile between compartments of transfer and changes during the lactation period. Mar Ecol Prog Ser 2003b;247:249-56.

Debier C, Chalon C, Le Boeuf BJ, De Tillesse T, Larondelle Y, Thomé JP. Mobilization of PCBs from blubber to blood in northern elephant seals (Mirounga angustirostris) during the post-weaning fast. Aquat Toxicol 2006;80:149-57.

de Boer J, Wester PG, Klamer HJC, Lewis WE, Boon JP. Do flame retardants threaten ocean life? Nature 1998;394:28-9.
Dorneles, P.R., Lailson-Brito, J., Covaci, A., Dirtu, A.C., Weijs, L., Azevedo, A.F., et al., Anthropogenic and naturally-produced organobrominated compounds in marine mammals from Brazil. Environ Pollut, submitted for publication.

Dunkin RC, McLellan WA, Blum JE, Pabst DA. The ontogenetic changes in the thermal properties of blubber from Atlantic bottlenose dolphin Tursiops truncatus. J Exp Biol 2005;208:1469-80.

Gebbink WA, Sonne C, Dietz R, Kirkegaard M, Riget FF, Born EW, et al. Tissue-specific congener composition of organohalogen and metabolite contaminants in East Greenland polar bears (Ursus maritimus). Environ Pollut 2008;152:621-9.

Haglund PS, Zook DR, Buser HR, Hu J. Identification and quantification of polybrominated diphenyl ethers and methoxy-polybrominated diphenyl ethers in Baltic biota. Environ Sci Technol 1997:31:3281-7.

Hammond PS, Berggren P, Benke H, Borchers DL, Collet A, Heide-Jørgensen MP, et al. Abundance of harbour porpoise and other cetaceans in the North Sea and adjacent waters. J Appl Ecol 2002;39:361-76.

Hasselmeier I, Fonfara S, Driver J, Siebert U. Differential hematology profiles of freeranging, rehabilitated, and captive harbor seals (Phoca vitulina) of the German North Sea. Aquat Mammals 2008;34:149-56.

Hobbs KE, Lebeuf M, Hammill MO. PCBs and OCPs in male harbour, grey, harp and hooded seals from the Estuary and Gulf of St Lawrence, Canada. Sci Total Environ 2002;296:1-18.

Hoekstra PF, Letcher RJ, O'Hara TM, Backus SM, Solomon KR, Muir DCG. Hydroxylated and methylsulfone-containing metabolites of polychlorinated biphenyls in the plasma and blubber of bowhead whales (Balaena mysticetus). Environ Toxicol Chem 2003;22:2650-8.

Houde M, Pacepavicius G, Wells RS, Fair PA, Letcher RJ, Alaee M, et al. Polychlorinated biphenyls and hydroxylated polychlorinated biphenyls in plasma of bottlenose dolphins (Tursiops truncatus) from the Western Atlantic and the Gulf of Mexico. Environ Sci Technol 2006;40:5860-6.

Hutchinson JD, Simmonds MP. Organochlorine contamination in Pinnipeds. Rev Environ Contam Toxicol 1994;136:123-67.

Huwe JK, Smith DJ. Accumulation, whole-body depletion, and debromination of decabromodiphenyl ether in male Sprague-Dawley rats following dietary exposure. Environ Sci Technol 2007;41:2371-7.

Jaspers VLB, Dirtu AC, Eens M, Neels H, Covaci A. Predatory birds species show different patterns of hydroxylated polychlorinated biphenyls (HO-PCBs) and polychlorinated biphenyls (PCBs). Environ Sci Technol 2008;42:3465-71.

Kajiwara N, Kannan K, Muraoka M, Watanabe M, Takahashi S, Gulland F, et al. Organochlorine pesticides, polychlorinated biphenyls, and butyltin compounds in blubber and livers of stranded California sea lions, elephant seals, and harbor seals from coastal California, USA. Arch Environ Contam Toxicol 2001;41:90-9.

Kastelein RA, van der Sijs SJ, Staal C, Nieuwstraten SH. Blubber thickness in harbour porpoises (Phocoena phocoena). In: Read AJ, Wiepkema PR, Nachtigall PE, editors. The biology of harbour porpoise. Woerden, The Netherlands: De Spill Publishers; 1997. p. 179-99.

Kelly BC, Ikonomou MG, Blair JD, Gobas FAPC. Hydroxylated and methoxylated polybrominated diphenyl ethers in a Canadian Arctic marine food web. Environ Sci Technol 2008:42:7069-77.

Koopman HN, Iverson SJ, Gaskin DE. Stratification and age-related differences in blubber fatty acids of the male harbour porpoise (Phocoena phocoena). J Comp Physiol B 1996;165:628-39.

Letcher RJ, Klasson-Wehler E, Bergman Å. Methyl sulfone and hydroxylated metabolites of polychlorinated biphenyls. In: Paasivirta J, editor. The Handbook of Environmental Chemistry. Berlin Heidelberg: Springer-Verlag; 2000. p. 315-59.

Lockyer C. All creatures great and smaller: a study in cetacean life history energetics. J Mar Biol Assoc UK 2007;87:1035-45

Løken KB, Lie E, Sørmo EG, Jenssen BM, Skaare JU. How important are the hydroxylated PCB metabolites (OH-PCB) in harbour seals (Phoca vitulina)? Organohalog Compd 2008;70:25-8.

Marsh G, Athanasiadou M, Athanassiadis I, Bergman A, Endo T, Haraguchi K. Identification, quantification and synthesis of a novel dimethoxylated polybrominated biphenyl in marine mammals caught off the coast of Japan. Environ Sci Technol 2005;39:8684-90.

McKinney MA, De Guise S, Martineau D, Béland P, Arukwe A, Letcher RJ. Biotransformation of polybrominated diphenyl ethers and polychlorinated biphenyls in beluga whale (Delphinapterus leucas) and rat mammalian model using an in vitro hepatic microsomal assay. Aquat Toxicol 2006a;77:87-97.

McKinney MA, De Guise S, Martineau D, Béland P, Lebeuf M, Letcher RJ. Organohalogen contaminants and metabolites in beluga whale (Delphinapterus leucas) liver from two Canadian populations. Environ Toxicol Chem 2006b;25:1246-57.

Meerts IA, van Zanden JJ, Luijks EA, Leeuwen-Bol I, Marsh G, Jakobsson E, et al. Potent competitive interactions of some brominated flame retardants and related compounds with human transthyretin in vitro. Toxicol Sci 2000;6:95-104

Meijer L, Weiss J, Van Velzen M, Brouwer A, Bergman Å, Sauer PJJ. Serum concentrations of neutral and phenolic organohalogens in pregnant women and some of their infants in The Netherlands. Environ Sci Technol 2008;42:3428-33.

Melcher J, Olbrich D, Marsh G, Nikiforov V, Gaus C, Gaul S, et al. Tetra- and tribromophenoxyanisoles in marine samples from Oceania. Environ Sci Technol 2005;39:7784-9.

Montie EW, Fair PA, Bossart GD, Mitchum GB, Houde M, Muir DCG, et al. Cytochrome P4501A1 expression, polychlorinated biphenyls and hydroxylated metabolites, and adipocyte size of bottlenose dolphins from the Southeast United States. Aquat Toxicol 2008;86:397-412.

Pirard C, De Pauw E. Absorption, disposition and excretion of polybrominated diphenyl ethers (PBDEs) in chicken. Chemosphere 2007;66:320-5.

Reijnders PJH, Aguilar A. Pollution and marine mammals. In: Perrin WE, Würisg B, Thewissen JGM, editors. Encyclopedia of marine mammals. Academic Press; 2002. p. 948-57. 
Reijnders P, Simmonds MP. Global temporal trends of organochlorines and heavy metals in pinnipeds. Toxicology of marine mammals. London: Taylor \& Francis; 2003. p. 491-506.

Ross P. Fireproof killer whales (Orcinus orca): flame retardant chemicals and the conservation imperative in the charismatic icon of British Columbia, Canada. Can J Fish Aquat Sci 2006;63:224-34.

Ruus A, Ugland KI, Espeland O, Skaare JU. Organochlorine contaminants in a local marine food chain from Jarfjord, Northern Norway. Mar Environ Res 1999;48:131-46.

Sandala GM, Sonne-Hansen C, Dietz R, Muir DCG, Valters K, Bennett ER, et al. Hydroxylated and methyl sulfone PCB metabolites in adipose and whole blood of polar bear (Ursus maritimus) from East Greenland. Sci Total Environ 2004;331:125-41.

Sandau CD, Meerts IATM, Letcher RJ, McAlees AJ, Chittim B, Brouwer A, et al. Identification of 4-hydroxyheptachlorostyrene in polar bear plasma and its binding affinity to transthyretin: a metabolite of octachlorostyrene? Environ Sci Technol 2000;34:3871-7.

Shaw SD, Brenner D, Bourakovsky A, Mahaffey CA, Perkins CR. Polychlorinated biphenyls and chlorinated pesticides in harbor seals (Phoca vitulina concolor) from the northwestern Atlantic coast. Mar Pollut Bull 2005;50:1069-84.

Shaw SD, Brenner D, Berger ML, Fang F, Hong CS, Storm R, et al. PBDEs, PCBs and dioxinlike PCBs in harbor seals from the northwestern Atlantic. Organohalog Compd 2007;69:829-32.

Shimokawa N, Miyazaki W, Iwasaki T, Koibuchi N. Low dose hydroxylated PCB induces c-Jun expression in PC12 cells. NeuroToxicology 2006;27:176-83.

Siebert U, Wünschmann A, Weiss R, Frank H, Benke H, Frese K. Post mortem findings in harbour porpoises (Phocoena phocoena) from the German North and Baltic Sea. J Comp Pathol 2001;124:102-14.

Sørmo, E.G. Organochlorine pollutants in grey seal (Halichoerus grypus) pups and their impact on plasma thyroid hormone and vitamin A concentrations. Faculty of Natural Sciences and Technology. Trondheim, Norway, Norwegian University of Science and Technology (NTNU). Dr. scient. thesis: 73 pp; 2005.

Sørmo EG, Skaare JU, Lydersen C, Kovacs KM, Hammill MO, Jenssen BM. Partitioning of persistent organic pollutants in grey seal (Halichoerus grypus) mother-pup pairs. Sci Total Environ 2003;302:145-55.

Stapleton HM, Alaee M, Letcher RJ, Baker JE. Debromination of the flame retardant decabromodiphenyl ether by juvenile carp (Cyprinus carpio) following dietary exposure. Environ Sci Technol 2004;38:112-9.

Tanabe S, Iwata H, Tatsukawa R. Global contamination by persistent organochlorines and their ecotoxicological impact on marine mammals. Sci Total Environ 1994;154:163-77.
Teuten EL, Reddy CM. Halogenated organic compounds in archived whale oil: a preindustrial record. Environ Pollut 2007;145:668-71.

Thomas GO, Moss SEW, Asplund L, Hall AJ. Absorption of decabromodiphenyl ether and other organohalogen chemicals by grey seals (Halichoerus grypus). Environ Pollut 2005;133:581-6.

Thron KU, Bruhn R, McLachlan MS. The influence of age, sex, body-condition, and region on the levels of PBDEs and toxaphene in harbour porpoises from European waters. Fresenius Environ Bull 2004;13:146-55.

Troisi GM, Haraguchi K, Kaydoo DS, Nyman M, Aguilar A, Borrell A, et al Bioaccumulation of polychlorinated biphenyls (PCBs) and dichlorodiphenylethane (DDE) methyl sulfones in tissues of seal and dolphin morbillivirus epizootic victims. J Toxicol Environ Health A 2001;62:1-8.

Van den Steen E, Covaci A, Jaspers VLB, Dauwe T, Voorspoels S, Eens M, et al Accumulation, tissue-specific distribution and debromination of decabromodiphenyl ether (BDE 209) in European starlings (Sturnus vulgaris). Environ Pollut 2007; 148:648-53.

Vetter W, Luckas B, Heidemann G, Skirnisson K. Organochlorine residues in marine mammals from the Northern hemisphere - a consideration of the composition of organochlorine residues in the blubber of marine mammals. Sci Total Environ 1996;86:29-39.

Vetter W. Marine halogenated natural products of environmental relevance. Rev Environ Contam Toxicol 2006;188:1-57.

Weijs L, Dirtu AC, Das K, Gheorghe A, Reijnders PJH, Neels H, et al. Inter-species differences for polychlorinated biphenyls and polybrominated diphenyl ethers in marine top predators from the Southern North Sea: part 1. Accumulation patterns in harbour seals and harbour porpoises. Environ Pollut 2009a;157:437-44.

Weijs L, Dirtu AC, Das K, Gheorghe A, Reijnders PJH, Neels H, et al. Inter-species differences for polychlorinated biphenyls and polybrominated diphenyl ethers in marine top predators from the Southern North Sea: part 2. Biomagnification in harbour seals and harbour porpoises. Environ Pollut 2009b;157:445-51.

Weiss J, Wallin E, Axmon A, Jonsson BAG, Akesson H, Janak K, et al. Hydroxy-PCBs, PBDEs, and HBCDDs in serum from an elderly population of Swedish fishermen's wives and associations with bone density. Environ Sci Technol 2006;40:6282-9.

Young D, Becerra M, Kopec D, Echols S. GC/MS analysis of PCB congeners in blood of the harbor seal Phoca vitulina from San Francisco Bay. Chemosphere 1998;37:711-33. 